JOURNAL OF BIOMEDICAL RESEARCH \& CLINICAL

PRACTICE

\title{
Optimisation of Biogas Production through Variation of PH, Detention Time and Ratio of Substrate to Water for Rural Utilization
}

Jiya AG, ${ }^{1}$ Ijah UJJ, ${ }^{2}$ Galadima $M,{ }^{2}$ Akpan UG ${ }^{3}$

Department of Biological Science, Federal Polytechnic Bida, Niger State Nigeria. ${ }^{{ }^{1}}$

Department of Microbiology ${ }^{2}$ and Department of Chemical Engineering ${ }^{3}$, Federal University of Technology Minna, Niger State Nigeria.

\section{ABSTRACT}

*Corresponding Author: Jiya AG, Biological Science, Federal Polytechnic Bida, Niger State Nigeria. Tel: 07030393603 Email: ganaibro74@yahoo.com

A response surface methodology (RSM) was utilized in this study for optimisation of biogas production process. The optimal values of process parameter capable of giving a high yield of biogas were established. A biodigester of 20 liters capacity capable of producing biogas from rural household domestic waste was designed, constructed and used in the study. Its major units are the anaerobic and gas collecting units. The process parameters investigated are the $\mathrm{pH}$ of the substrate, detention time and ratio of substrate to water while the yield of biogas was used as performance characteristics. The experiment was based on a central composite rotatable design (CCRD). The results revealed that the highest yield of biogas was obtained from a combination of detention time of 30 days, ratio of substrate to water of 1:1 and $\mathrm{pH}$ of 7, while the least yield of biogas of 11 $\mathrm{cm} 3$ was obtained from combination of detention time of 30 days, ratio of substrate to water of 1:3 and $\mathrm{pH}$ of 2 . Numerical optimization carried out with the goal of maximizing the biogas yield revealed optimum values of detention time of 40 days, the ratio of substrate and water used; $1: 2$ and $\mathrm{pH}$ of 6.71 for biogas of $771.77 \mathrm{~cm} 3$ with the desirability of 0.9850 . The detention time had the highest significant effects on the yield of biogas. The results of this study provided standard input process variables capable of yielding the optimum yield of biogas for the rural community.

Keywords: Biogas, Domestic waste, Optimisation, Response surface methodology

\section{INTRODUCTION}

$\mathrm{E}$ nergy plays an important role in the socio-economic development of many Countries. It is widely recognized that energy is linked in various ways in reducing poverty, improving human well-being and living standards. The demand of energy requirement is directly proportional to the development and population growth rate of a country. ${ }^{1}$ Basically energy is available in the form of renewable and nonrenewable energy. The non-renewable energy is from sources that cannot be replenished. Most non-renewable energy sources are fossil fuels: coal, petroleum, and natural gas. Fossil fuels especially petroleum is the most used form of energy in most
2018 Joumal Impact Factor: 1.10

Print ISSN: 2636-7378 | Online ISSN: 2651-5865

developing countries. The major concern about this source of energy are its limited nature and negative impacts on the environment, with a particular focus on the global climate change that is caused by increasing concentrations of greenhouses gases. The development of an alternative energy source has being in the forefront of research and renewable energy source was identified as one of them. ${ }^{2}$ Renewable energy sources are energy sources that are constantly being replenished, such as sunlight, wind, water and biomass. 
This form of energy has infinite sustainability. It is clean and produces little or no greenhouse and net carbon emissions. It does not deplete natural resources and have minimal, if any, adverse effect on the environment. It is reliable, cheaper and more economically sound than other sources of generated energy. In recent years, biogas a renewable source of energy has been receiving increasing attention as an alternative to fossil fuels in solving the problems of rising energy prices, waste management and creating a sustainable development. ${ }^{3}$ Biogas refers to a mixture of different gases produced by the breakdown of organic matter in the absence of oxygen. Biogas can be produced from raw materials such as agricultural waste, manure, municipal waste, plant material, sewage, green waste or food waste. Biogas technology plays an important role in producing energy from renewable energy. ${ }^{4}$ In the rural areas of Nigeria, fire wood is the form of energy source used for preparation of food. It is in the form of logs and branches from trees.

Firewood (fuel wood) is defined by the Food and Agriculture Organization of the United Nations (FAO) as "wood in the rough (from trunks and branches of trees) to be used as fuel for purposes such as cooking, heating or power production. ${ }^{5}$ The burning of firewood has a negative impact on health due to high emissions of gases, such as respiratory, heart diseases, lung cancer, and eye irritations. ${ }^{6}$ Therefore biogas technology was considered as an alternative source of renewable energy, capable of producing clean resources, in addition to its applicability in management of organic waste from the industry and household sectors. ${ }^{4}$ Furthermore, it is a flexible form of renewable energy that can produce heat, electricity and is commonly used for cooking, lighting and serves as fuel for vehicle. $^{7}$ Therefore, this study focused on optimisation of biogas production through variation of $\mathrm{pH}$, detention time and ratio of substrate to water, for rural utilization.

\section{MATERIALS AND METHODS}

\section{Collection and Processing of Samples}

The substrates used in this study were domestic household wastes which include: carbohydrate food wastes (yam peels and products, potato peels, cassava peels products, corn cobs and corn products), leafy vegetables and orange peels as well as fat and protein rich food wastes(beans and beans products, egg shells, fish crumps, ground nut shells). These were from Ndawangwa village in Lavun Local Government Area of Niger
State, Nigeria. To collect the domestic household wastes ten (10) clean waste bags were distributed to ten (10) households for a period of one month. The waste bags were collected and emptied into two clean waste containers in the village. All the samples collected were transported to the laboratory and airdried at room temperature $\left(28 \pm 2^{\circ} \mathrm{C}\right)$ for seven days, pounded using a clean mortar and pestle, kept in air-tight containers for further processing.

\section{Equipment}

A 20 liters capacity biodigester capable of producing biogas from household domestic waste was designed and constructed using metallic chaka plate. The digester consists of anaerobic chamber and gas collecting chamber. In between the two chambers is a narrow passage which allows the flow of gas from anaerobic chamber to gas chamber. A short valve of 10 mm diameter conveyed the gas from gas chamber to element for burning. In between the burner and gas chamber was a knob which served to regulate the biogas flow as shown in Plate $1 .^{8,9,10}$

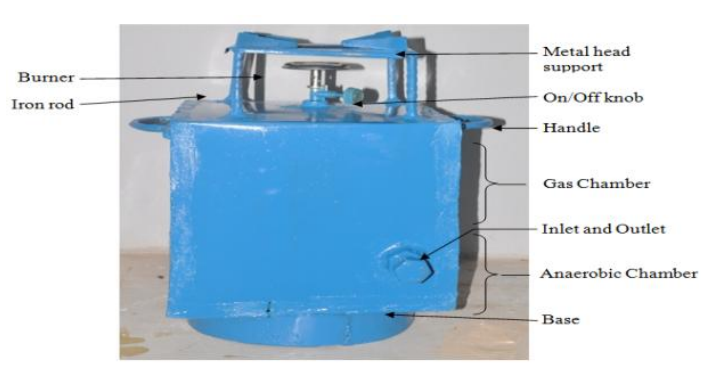

Plate 1: Biogas production design for rural communities

\section{Experimental setup and plan}

A Response Surface Methodology was employed in this study using central composite rotatable design (CCRD). It consisted of three factors which were varied at five levels (Gana et al. 2018). The CCRD consisted of 20 experimental runs ( $2 k+2 k+$ $\mathrm{m}$, where $\mathrm{k}$ is the number of factors and $\mathrm{m}$ the number of replicated centre points), comprised of eight factorial points (2k), six axial points $(2 \mathrm{k})$, and six replicated centre points $(\mathrm{m}=$ 6). The $\mathrm{k}$ is the number of independent variables and the axial points have $\alpha=1.68$. Results from previous research were used to establish a centre point of the CCRD for each factor. ${ }^{11,12}$ 
Table 1: Matrix Transformation of Five Level- Three Factors Central Composite Rotatable Design of the Experiment

\begin{tabular}{|c|c|c|c|c|c|}
\hline $\begin{array}{l}\text { Standard } \\
\text { Order }\end{array}$ & $\begin{array}{l}\text { Run } \\
\text { Order }\end{array}$ & $\begin{array}{l}\text { Detention } \\
\text { Time (day) }\end{array}$ & $\begin{array}{l}\text { Ratio of } \\
\text { Substrate to } \\
\text { Water } \\
\end{array}$ & pH & $\begin{array}{l}\text { Yield } \\
\text { of biogas }\end{array}$ \\
\hline 10 & 1 & 47 & $1: 3$ & 7 & 642 \\
\hline 17 & 2 & 30 & $1: 3$ & 7 & 654 \\
\hline 19 & 3 & 30 & $1: 3$ & 7 & 482 \\
\hline 16 & 4 & 30 & $1: 3$ & 7 & 570 \\
\hline 11 & 5 & 30 & $1: 1$ & 7 & 783 \\
\hline 18 & 6 & 30 & $1: 3$ & 7 & 511 \\
\hline 20 & 7 & 30 & $1: 3$ & 7 & 510 \\
\hline 4 & 8 & 40 & $1: 4$ & 4 & 212 \\
\hline 7 & 9 & 20 & $1: 4$ & 10 & 148 \\
\hline 9 & 10 & 13 & $1: 3$ & 7 & 218 \\
\hline 6 & 11 & 40 & $1: 2$ & 10 & 512 \\
\hline 15 & 12 & 30 & $1: 3$ & 7 & 412 \\
\hline 14 & 13 & 30 & $1: 3$ & 12 & 34 \\
\hline 2 & 14 & 40 & $1: 2$ & 4 & 571 \\
\hline 5 & 15 & 20 & $1: 2$ & 10 & 143 \\
\hline 13 & 16 & 30 & $1: 3$ & 2 & 11 \\
\hline 1 & 17 & 20 & $1: 2$ & 4 & 254 \\
\hline 3 & 18 & 20 & 4 & 4 & 112 \\
\hline 8 & 19 & 40 & 4 & 10 & 243 \\
\hline 12 & 20 & 30 & $1: 5$ & 7 & 242 \\
\hline
\end{tabular}

Key: $\mathrm{pH}=$ Hydrogen ion Concentration

The three factors (process parameters) are detention time, ratio of substrate to water and $\mathrm{pH}$ of the substrate. The detention time was varied at $13,20,30,40$ and 47 days, ratio of substrate to water was varied at ratio of 1:1, 1:2, 1:3, 1:4 and 1:5. The $\mathrm{pH}$ was varied at 2, 4, 7, 10 and 14 respectively. The experiment was conducted based on the design matrix shown in Table 1 . The process parameters were the independent variables while the yield of biogas was the dependent variable (response).

\section{Experimental procedure}

The performance of digester and yield of gas was evaluated in accordance with standard method and procedure described by Nnabuchi $e a^{13}$ and Theresia and Priadi. ${ }^{14}$ Twenty samples of ten kilograms $(10 \mathrm{~kg})$ of waste each were prepared. The samples were used to prepared slurry by adding specific amount of water as shown in Table 1 . The $\mathrm{pH}$ of the samples was varied as in Table 1 with the help of $0.1 \mathrm{M}$ sodium hydroxide buffer solution. Each of the samples was loaded into the digester and seeded with three $3 \mathrm{~kg}$ portions of starter culture (digest of the laboratory digester). The retention time was also varied as in Table 1 and the experiment was carried out under room temperature $(28.5 \pm 2)$. The biogas readings were taken using a sensitive hanging weighing balance. This was done by taking the difference between the weight of biodigester with the substrate and weight of the biodigester with substrate and biogas.

The effects of biogas production parameters such as detention time, ratio of substrate to water and $\mathrm{pH}$ of the substrate on yield of biogas were investigated. The results of the experiment were analysed and optimum production parameters capable of yielding maximum biogas were established.

\section{Optimisation Analysis}

Optimisation is the process of finding the best substrate and production parameters for a system or operation. The main purpose of optimisation is to achieve optimum conditions for the operation of a system or biodigester plant in producing biogas. In this study, the optimisation analysis of the independent variables and the dependent variable were carried out using the numerical technique in Design expert software as reported by Aworanti et al. ${ }^{15}$ and Gana et al. ${ }^{16}$ who studied the development and testing of an automated grain drink processing machine.

\section{Statistical analysis}

Design expert software package (version 7.0.0) was used for the regression and graphical analysis. A quadratic polynomial equation was developed to predict the response as a function of independent variables and their interaction. In general, the response for the quadratic polynomials is described below as reported by Aworanti et al. ${ }^{15}$

$Y=\mathrm{f}(\mathrm{D}, \mathrm{R}, \mathrm{P})$
$Y=\beta_{o}+\beta_{1} D+\beta_{2} R+\beta_{3} P$

Where $\beta_{0}, \beta_{1}, \beta_{2}, \beta_{3}$ are the coefficients to be estimated, $D, R$ and $\mathrm{P}$, are the constraints or independent variables and $\mathrm{Y}$ are the objective functions (dependent variables). Analysis of variance (ANOVA) was carried out to estimate the effects of main variables and their potential interaction effects on the yield of the biogas. 


\section{RESULTS}

\section{Effects of production Parameters on Biogas Yield}

The digester production parameters investigated in this study were detention time, ratio of substrate to water and $\mathrm{pH}$ of the substrate. The relationship between the independent variables; detention time, ratio of substrate to water, $\mathrm{pH}$ of the substrate with the yield of the biogas is presented in Table 1. The results revealed that the yield of biogas ranged between $11 \mathrm{~cm}^{3}$ and $783 \mathrm{~cm}^{3}$. The highest value of $783 \mathrm{~cm}^{3}$ was obtained from combination of detention time of 30days, ratio of substrate to water of 1:1 and $\mathrm{pH}$ of 7, while the least yield of biogas of 11 $\mathrm{cm}^{3}$ was obtained from combination of detention time of 30days, ratio of substrate to water of $1: 3$ and $\mathrm{pH}$ of 2 .

The result of the statistical analysis of variance (ANOVA) of the experiment (Table 2) showed that the model terms were significant. The significant model terms were identified at $95 \%$ significance level. The Quadratic regression model equation developed to predict the yield of biogas with respect to process parameters (independent variables) is shown in equations 3 and 4. The results of the data ANOVA analysis in Table 2 showed the model equation was significant $(\mathrm{P} \leq 0.0001)$ implied that there were only 0.01 possibilities that a big Model $F$ value of 17.97 might occur as result of noise. The results further indicated that the detention time and ratio of substrate to water were significant Model terms $(\mathrm{P} \leq 0.05)$. It can be clearly observed that A (detention time) has the highest significant effects on the yield of biogas with value of coefficient of estimate of 116.72. Also, the lack of fit F-value of 0.64 means that it is insignificant relative to pure error. There was $68.16 \%$ possibility that F-value was unfit. This big value might occur as a result of noise. Insignificant of unfit value is good because if it is significant then the model equation will not be able to predict the response. ${ }^{15,16}$

The coefficient of determination $\mathrm{R}$ value of 0.9705 indicated that the Model equation was capable of predicting about $97.05 \%$ of the differences between the predicted and experimental values. Therefore, the Model was not capable to account for only $2.95 \%$ of the variation. The coefficient of correlation $\mathrm{R}$ - Square value of 0.9418 was high very close to 1 as recommended by Xin and Saka. ${ }^{17}$ But the author further reported that large value of $\mathrm{R}^{2}$ does not always suggest that regression model equation is a good one because it will increase when a variable is added even though the new variable is of significant or otherwise.

Table 2: Regressional Analysis of Response of Biogas Yield

\begin{tabular}{|c|c|c|c|c|c|c|}
\hline Source & $\begin{array}{l}\text { Coefficien } \\
\text { Estimate } \\
\end{array}$ & $\begin{array}{l}\text { Standard } \\
\text { Error }\end{array}$ & $\begin{array}{l}\text { F } \\
\text { Value }\end{array}$ & $\begin{array}{l}\text { p-value } \\
\text { Prob F }\end{array}$ & \multicolumn{2}{|c|}{$\begin{array}{l}\text { R-Squared } \\
\text { Value }\end{array}$} \\
\hline Model & 524.5844 & 30.3183 & 17.97 & $<.0001$ & 0.9418 & Significant \\
\hline A-DT & 116.7238 & 20.1155 & 33.6710 & 0.0002 & & \\
\hline B-AS & -122.638 & 20.1155 & 37.1696 & 0.0001 & & \\
\hline $\mathrm{C}-\mathrm{pH}$ & -10.867 & 20.1155 & 0.2918 & 0.6009 & & \\
\hline $\mathrm{AB}$ & -61.375 & 26.2821 & 5.4533 & 0.0417 & & \\
\hline $\mathrm{AC}$ & 5.875 & 26.2821 & 0.0499 & 0.8276 & & \\
\hline $\mathrm{BC}$ & 29.625 & 26.2821 & 1.2705 & 0.2860 & & \\
\hline $\mathrm{A}^{2}$ & -42.2049 & 19.5819 & 4.6453 & 0.0566 & & \\
\hline $\mathrm{B}^{2}$ & -13.0368 & 19.5819 & 0.4432 & 0.5206 & & \\
\hline$C^{2}$ & -177.439 & 19.5819 & 82.1086 & $<0.0001$ & & \\
\hline \multicolumn{2}{|c|}{ Lack of Fit } & & 0.6405 & 0.6816 & & not significant \\
\hline
\end{tabular}

Hence, adjusted and predicted $\mathrm{R}^{2}$ were suggested to be used to test the model adequacy. Based on that it was observed that the predicted R - square and Adjusted R - square values were in logical conformity with each other, the value of 0.7759 and 0.8894 respectively.

This means that experimental data were well fitted. All these pointed out that the model is adequately well fitted and thus, might predict the effects of the independent variables on the yield of biogas up to nearly $97 \%$. Model precision measures the ratio of signal to noise and minimum value of 4 was reported by Salam et al. ${ }^{18}$ as desirable value. The value model precision of 13.12 obtained means adequate signal, thus the model equation can be employed to navigate the design area.

The Quadratic regression model and fitted model equations developed to predict the yield of biogas with respect to biogas production parameters (independent variables) were given as shown in equations 3 and 4.

$\mathrm{Y}_{\mathrm{B}}=524.58+116.72 A-122.64 B-10.87 C-61.37 A B+5.88 A C+$ $29.63 B C-42.20 A^{2}-13.04 B^{2}-177.44 C^{2}$

$\mathrm{Y}_{\mathrm{B}}=$ the Yield of Biogas $\left(\mathrm{cm}^{3}\right), \mathrm{A}=$ Detention Time (Days), $\mathrm{B}=$ Ratio of substrate to water, $\mathrm{C}=\mathrm{pH}$ of the substrate. The developed equations contain both significant and insignificant terms. Model terms with $\mathrm{p}$ - value greater than 0.5000 were not 
significant model terms (that is $\mathrm{C}, \mathrm{AC}, \mathrm{BC}, \mathrm{A}^{2}, \mathrm{~B}^{2}$ were not significant) and since these terms were insignificant.

The fitted model is presented in equation 2 as reported by Gana et al. ${ }^{18}$

$\mathrm{Y}_{\mathrm{B}}=524.58+116.72 A-122.64 B-61.37 A B-177.44 C^{2}$

It is important to add that the variable $\mathrm{A}$ (detention time) in the fitted model has positive co-efficient implying a direct proportionality, while B (ratio of substrate to water) has negative co-efficient implying an indirect proportionality. That is independent increase in A increase the biogas yield while in $\mathrm{B}$ decreased the biogas yield.

\section{The Response Surface and Contour Plot for the Yield of Biogas with respect to Detention Time and pH of the Substrate}

The response surface and contour plot for yield of biogas with respect to detention time and $\mathrm{pH}$ of the substrate are presented in Figures 1 and 2 respectively. The yield of biogas increased significantly $(\mathrm{P} \leq 0.05)$ from $150 \mathrm{~cm}^{3}$ to $497 \mathrm{~cm}^{3}$ as the detention time increased from 20 days to 40 days at the $\mathrm{pH} 2$. Also, at $\mathrm{pH} 7$, the yield of the biogas increased significantly ( $\mathrm{P}$ $\leq 0.05$ ) from $345 \mathrm{~cm}^{3}$ to $610 \mathrm{~cm}^{3}$ with increase in detention time from 20 days to 40 days. This indicated increase in biogas yield with increase in detention time. On the other hand, at the 20 days detention time the yield increased significantly ( $\mathrm{P} \leq$ 0.05 ) from 187 to $345 \mathrm{~cm}^{3}$ with increase in $\mathrm{pH}$ from 4 (acidic) to 7 (neutral) and then further decreased to $182 \mathrm{~cm}^{3}$ with further increase in the $\mathrm{pH}$ up to $\mathrm{pH} 10$. In addition, at the detention time of 40 days, the yield increased from $400 \mathrm{~cm}^{3}$ to $600 \mathrm{~cm}^{3}$ with increase in $\mathrm{pH}$ from 4 to 7 and then decreased with further increase in $\mathrm{pH}$.

This contrasted the study conducted by Rabah et al. ${ }^{20}$ and Otun et al. ${ }^{21}$ who observed a decrease in $\mathrm{pH}$ but increase in detention time which is in conformity with the present study. The gradual reduction in $\mathrm{pH}$ might be attributable to gradual change of state of generation of biogas, from hydrolysis to acidogenesis in which the slurry becomes more acidic and forms substrate that was acted on by methanogenic bacteria to produce biogas. The present findings conform to the report of Gerardi ${ }^{22}$ which recommended that the $\mathrm{pH}$ of anaerobic digester should be maintained between 6 and 8; otherwise, the growth of methanogenes will be seriously inhibited. The longer period of inactivity might also be due to inability of the substrate to decompose faster due to lignocellulosic substances which implies low biogas yield. ${ }^{23}$ The significant increase in biogas yield $(\mathrm{p} \leq 0.05)$ with increase in detention time agrees with the report of Sambo et al. ${ }^{24}$

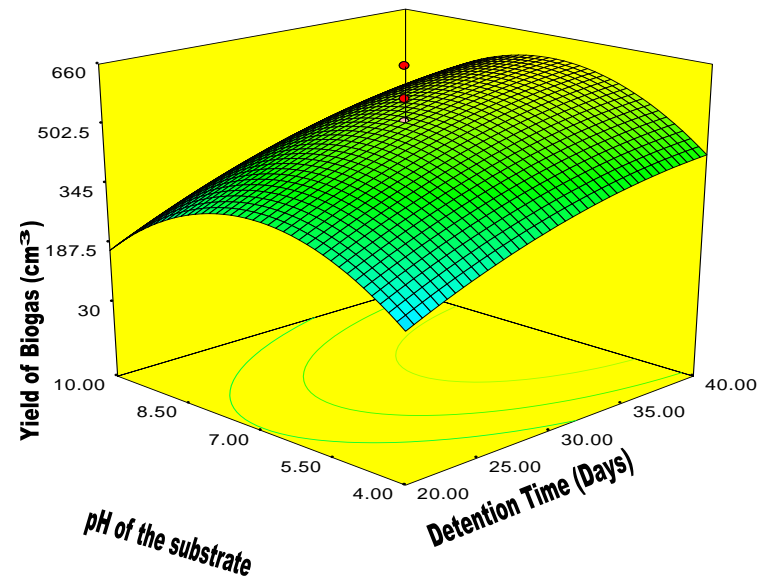

Figure 1: Response Surface and Contour Plot for the Yield of Biogas with respect to Detention Time and $\mathrm{pH}$ of the Substrate

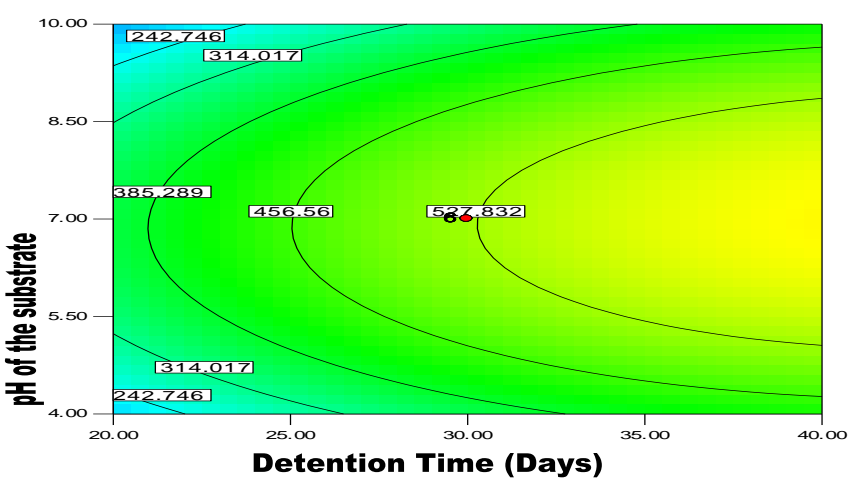

Figure 2: Contour Plot for Yield of Biogas with respect to Detention Time and $\mathrm{pH}$ of the Substrate

\section{The Response Surface and Contour Plot for the Yield of Biogas with respect to Ratio of substrate to water and $\mathrm{pH}$}

The response surface and contour plot for yield of biogas with respect to ratio of substrate to water and $\mathrm{pH}$ of the substrate are presented in Figures 3 and 4 respectively. The yield of biogas decreased significantly $(\mathrm{P} \leq 0.05)$ from $410 \mathrm{~cm}^{3}$ to $220 \mathrm{~cm}^{3}$ as the ratio of water increased from 2 to 4 . On the other hand, the yield increased significantly $(\mathrm{P} \leq 0.05)$ from $400 \mathrm{~cm}^{3}$ to 605 $\mathrm{cm}^{3}$ as the $\mathrm{pH}$ increased from 4 to 7 and then decreased to 410 $\mathrm{cm}^{3}$ with further increase in $\mathrm{pH}$ up to $\mathrm{pH} 10$. This is in lined with the findings of Iyagba et al. ${ }^{23}$ The water content for each sample should be determined using the recommendation that 
total solid is $8 \%$ in the fermentation slurry. This was the basis for the determination of the amount of water to be added to any given mass of total solid. ${ }^{23}$ The present study contrasts that of Chomini et $a l_{.}^{25}$ in the aspect of ratio of substrate to water in their work where ratio of $1: 3 \mathrm{w} / \mathrm{v}$ was used against the ratio of $1: 1 \mathrm{w} / \mathrm{v}$.

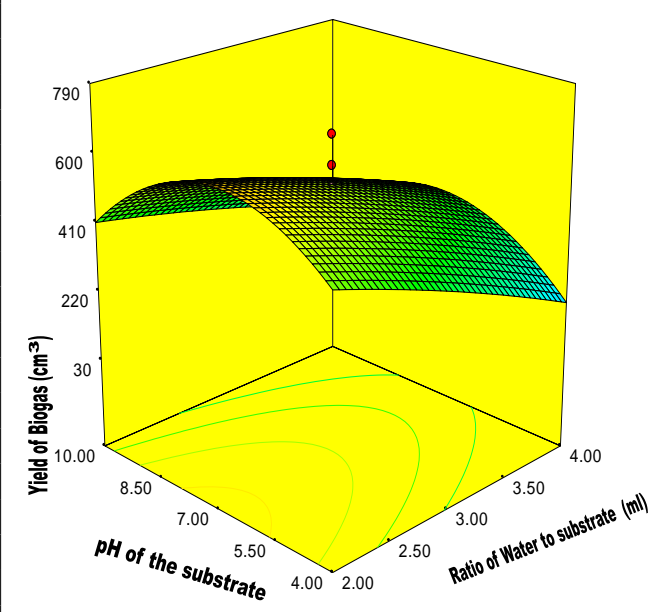

Figure 3: Response Surface and Contour Plot for the Yield of Biogas with respect to Ratio of Substrate to Water used and $\mathrm{pH}$ of the Substrate

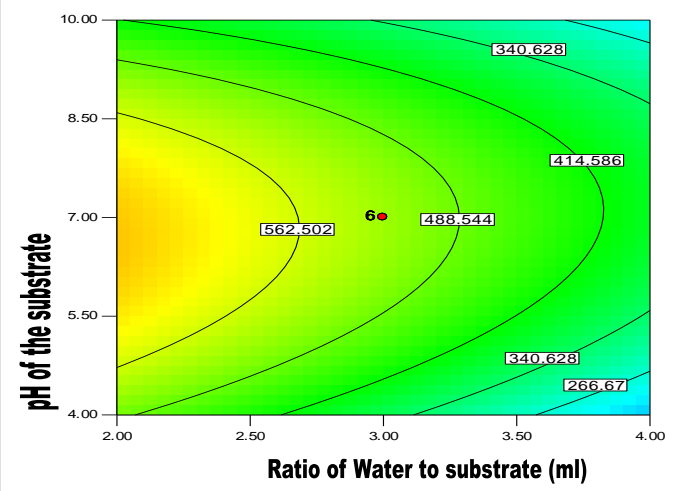

Figure 4: Contour Plot for the Yield of Biogas with respect to Ratio of Substrate to water used and $\mathrm{pH}$ of the Substrate.

\section{The Response Surface and Contour Plot for the Yield of Biogas with respect to Ratio of substrate to water and Detention Time}

The response surface and contour plot for yield of biogas with respect to ratio of substrate to water and detention time is presented in Figures 5 and 6 respectively. The yield of biogas decreased significantly $(\mathrm{P} \leq 0.05)$ from $400 \mathrm{~cm}^{3}$ to $280 \mathrm{~cm}^{3}$ as the ratio of water increased from 2 to 4 . On the other hand the yield increased significantly $(\mathrm{P} \leq 0.05)$ from $400 \mathrm{~cm}^{3}$ to 750 $\mathrm{cm}^{3}$ as the detention time increased from 20 days to 40 days.
This agrees with the report of Asikong et al. ${ }^{19}$ and Rabah et $a l^{20}$

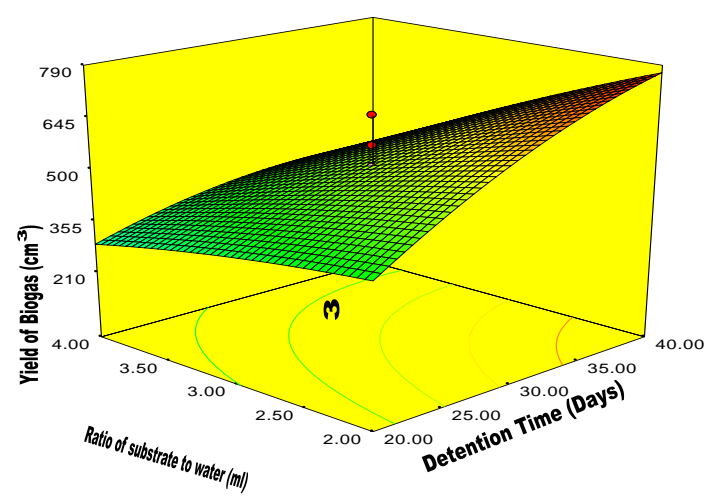

Figure 5: Response surface and Contour Plot for Yield of Biogas with respect to Detention Time and Ratio of Water used

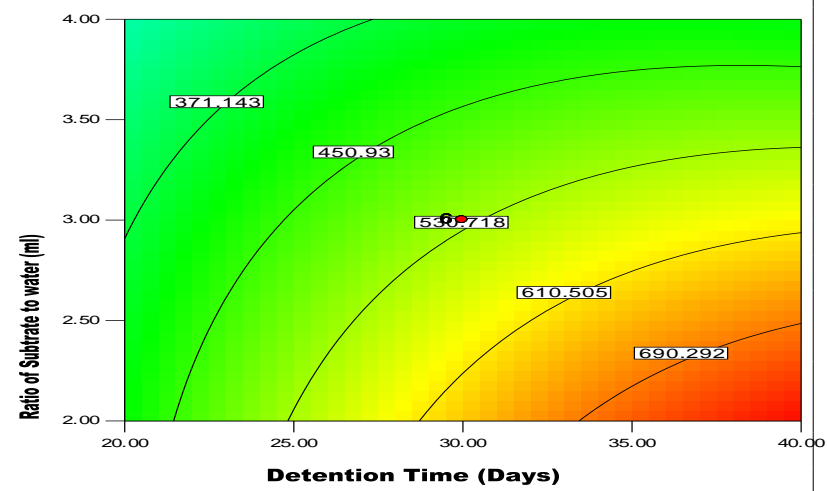

Figure 6: Contour Plot for the Yield of Biogas with respect to detention time and Ratio of Water used

\section{Optimisation of Biodigester Performance and Biogas Yield parameters}

Numerical optimisation was performed to maximise the yield of biogas. By employing the desirability function method in RSM, 8 solutions were obtained for the best covering criteria with desirability value close to 1 . In this case, first solution was selected as good desirability for maximum yield of gas with desirability of 0.9850 which was closest to 1 as shown in Figure 7

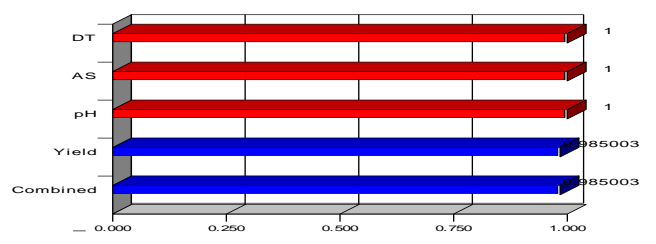

Figure 7: Bar Graph for Optimisation Desirability

J Biomed Res Clin Pract | Vol 2 | No 1 | 2019 


\section{Ramp for the Optimization}

The ramp for the optimisation is shown in Figure 8; it gave the optimum values of detention time of 40 days, ratio of substrate to water used; $1: 2$ and $\mathrm{pH}$ of 6.71 for biogas yield of 771.77 $\mathrm{cm}^{3}$ and desirability of 0.9850 .
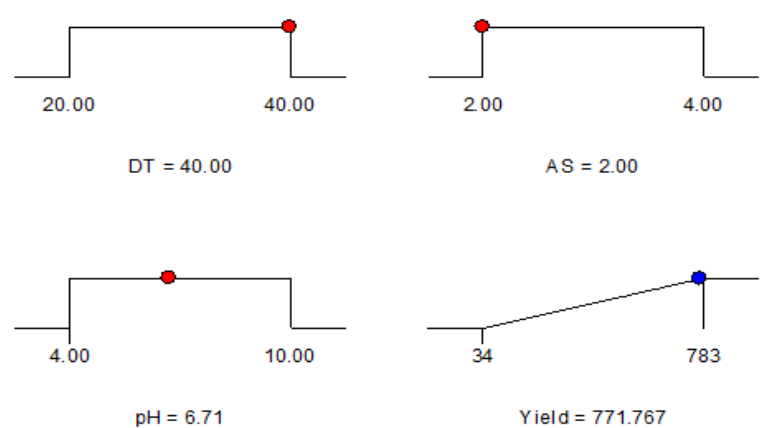

$\mathrm{pH}=6.71$

Yield $=771.767$

Desirability $=0.9850$

Figure 8: Ramp for Optimisation of biodigester Performance and biogas yield Parameters

\section{CONCLUSION}

The effects of process parameters of biogas production on biogas yield were studied and major conclusion were as follows: the yield of biogas increased from $150 \mathrm{~cm}^{3}$ to $497 \mathrm{~cm}^{3}$ as the detention time increased from 20 days to 40 days at the $\mathrm{pH}$ 2. The yield of biogas decreased from $410 \mathrm{~cm}^{3}$ to $220 \mathrm{~cm}^{3}$ as the ratio of water increased from 2 to 4 . Also the yield increased from $400 \mathrm{~cm}^{3}$ to $605 \mathrm{~cm}^{3}$ as the $\mathrm{pH}$ increased from 4 to 7 and then decreased to $410 \mathrm{~cm}^{3}$ with further increase in $\mathrm{pH}$ up to $\mathrm{pH}$ 10.Optimum values of values of detention time of 40 days, ratio of substrate to water used; $1: 2$ and $\mathrm{pH}$ of 6.71 for biogas yield of $771.77 \mathrm{~cm}^{3}$ with a desirability of 0.9850 .

\section{RECOMIMENDATIONS}

We recommend that other household domestic waste not used in this study should be harnessed for biogas production, government and other relevant bodies should embark on and encourage more researches in rural biogas technology, adopt and commercialize small scale digesters to serve as means of producing and providing cooking gas for rural dwellers. This will go a long way to reduce the demand for wood from the forest and the impact of green house gas emission in Nigeria. Biogas production should be optimised through other variables or physicochemical parameters not used in this research.

\section{Conflict of Interest}

None declared

\section{REFERENCES}

1. Komala HP, and Devi Prasad AG. Biomass: a key source of energy in rural households of chamarajanagar district. Advances in Applied Science Research 2016: 7(1):85-89. Available from http://www.imedpub.com/articles/biomassa-key-source-of-energy-in-rural-householdsofchamarajanagar-district.pdf

2. Ahmed SAE, Osman AAM. Renewable energy advantages and disadvantages. International Journal of Research Science \& Management [Internet]. 2016,3(10):7-9. Available from ftp://ftp.fao.org/docrep/fao/007/j4504e/j4504e00.pdf

3. Mshandete AM, Parawira W. Biogas Technology Research in Selected Sub-Saharan African Countries - A review. African Journal of Biotechnology; 2009; 8(2): 116-125.

4. Alfarjani FAB. Design and optimization of process parameters in bio-gas production systems. Master of Engineering (M. Eng), 2012, School of Mechanical and Manufacturing Engineering Dublin City University, 1-10.

5. FAO. Unified Bioenergy Terminology; 2004 [cited 2018 Aug 10].Available from http://www.fao.org/docrep/007/j4504E/j4504e00.htm

6. Bailis R.Impacts of greenhouse gas and particulate emission from woodfuel production and end-use in SubSaharan Africa; 2003 [cited 2018 Aug 15]. Available from file:///C:/Users/USER/AppData/Local/Temp/IMPACTS_O F_GREENHOUSE_GAS_AND_PARTICULATE_EMISS ION.pdf

7. Marchaim U.Biogas processes for sustainable development, MIGAL GalileeTechnological Centre KiryatShmona, Israel; 2002 [cited 2018 Sept 18]. Available from

https://sswm.info/sites/default/files/reference_attachments/ MSHANDETE\%20\&\%20PARAWIRA\%202008\%20Biog as\%20Technology\%20Research\%20in\%20Selected\%20Su b Saharan\%20African\%20Countries.pdf

8. Tom B, Templeton RM.History and future of domestic biogas plants in the developing world. Energy for Sustainable Development; 2011; 15: 347-354. Available from http://epubs.surrey.ac.uk/840974/ 
9. Oguwande GA, Osunade JA,Adeagbo AO, Fakuyi O.F. Effects of co-digesting swine manure with chicken manure on biogas production in Ile-ife, Nigeria. Ife Journal of Science; 2013; 15(1): $2-8$.

10. Asikong BE, Epoke J, Agbeo BE. Antai EE,Eja M.E. Four potentials of biogas yield from cow dung (CD) in Cross River State, Nigeria. European Journal of Experimental Biology; 2013; 3(3): 273 - 282. Available from http://www.sciencedomain.org/abstract/2557

11. Anders J, ReidunP, Hugh R. Anne-Kristin L. Anaerobic digestion of animal manure -implications for crop yield and soil biota in organic farming. Norwegian Journal for Agricultural and Environmental Research; 2015; 25(1): 97 102.

12. Muthu D, Venkatasubramanian C, Ramakrishnan K, Sasidhar, J. Production of Biogas from wastes blended with CowDung for Electricity generation -A case study (India). IOP Conference Series: Earth And Environmental Science;2017; 80. Available from http://197.210.8.200

13. Nnabuchi MN, Akubuko FO, Augustine C, Ugwu GZ, (2012). Assessment of the effect of co-digestion of Chicken dropping and Cow dung on Biogas generation. Global Journal of Science frontier Research: Physics and Space sciences; 2012; 12(7): 234-239. Available from https://globaljournals.org/GJSFR_Volume12/3-Assessmentof-the-Effect-of-Co-Digesti.pdf

14. Theresia M, Priadi CR.Optimization of methane production by combining organic waste and cow manure as feedstock in anaerobic digestion. American Institute of Physics Proceedings; 2017; 1826,020030. Available from https://doi.org/10.1063/1.4979246

15. Aworanti OA, Agarry AO, Ajani AO. Statistical Optimization of process variables for biodiesel production from waste cooking oil using heterogeneous base catalyst. British Biotechnology Journal; 20173(2): 116-132. Available from http://www.sciencedomain.org/abstract/933

16. Gana IM, Agidi G, Idah PA, Anuonye JC. Development and testing of an automated grain drinks processing machine. Journal of Food and Bioproducts Processing, Elsevier; 2017; 104: 19-31.Availablefrom https://www.sciencedirect.com/journal/food-and-bioproductsprocessing/vol/104

17. Xin L. Saka S. Optimization of Japanese beech hydrolysis treated with batch hot compressed water by response surface methodology. InternationalJournal of Agricultural Biological and Engineering; 2008; 1(2): 239-245. Available from https://ijabe.org/index.php/ijabe/issue/view/2/showToc
18. Salam KK, Arinkoola AO, Oke EO, Adeleye JO. Optimization of Operating Parameters Using Response Surface Methodology for Paraffin-Wax Deposition in Pipeline. Petroleum and Coal; 2014; 56(1):19-

28.Availablefrom https://www.vurup.sk/petroleum/2014/volume-56/

19. Gana IM, Gbabo A, Shehu AA, Mohammed KM, Dauda SM, Ahmad D. An investigative study on the effects of mechanical parameters of an automated grain drinks processing machine on drink consistency. Food Research; 2018; 2 (6) : 505 - 51. Available from http://www.myfoodresearch.com1

20. RabahAB, Baki, AS, Hassan LG, Musa M, Ibrahim AD.Production of Biogas using abattoir waste at different detention time in Sokoto, Nigeria, Science World Journal; 2010; 5(4): 23 - 26. Available from file://C:/Users/USER/AppData/Local/Temp/8597-29425-1PB.pdf

21. Otun TF, Ojo OM, Ajibade FO, Babatola JO.Evaluation of biogas production from the digestion and Co-digestion of animal waste, food waste and fruit waste. International Journal of Energy and Environmental Research; 2015; 3(3): 12-24.Availablefrom

http://www.eajournals.org/wpcontent/uploads/Evaluation-ofBiogas-Production-from-the-Digestion-and-Co-Digestion-ofAnimal-Waste-Food-Waste-and-Fruit-Waste.pdf

22. Gerardi MH. The Microbiology of Anaerobic Digesters. Waste water microbiology serials, New Jersey: JohnWiley, and Sons Inc Publication; 2003; 74 - 117.

23. Iyagba ET. Mangibo TA. Mohammed YS. The study of cow dung as co-substrate with rice husk in biogas production. Science Research Essays;2009; 4(9) 861-866.

24. Sambo AS. Renewable Energy Policy and Master Plan, Paper Presentation at the National Workshop on Creating Legislative Frame Work and Awareness for the Use of Alternative Energy for Sustainable Development in Calabar, Cross River State, Nigeria; 2015; 3(11): 7-16

25. Chomini MS, Ogbonna CIC, Falemara BC, Micah P. Effect of co-digestion of Cow dung and poultry manure on biogas yield, proximate and amino acid contents for their effluents. IOSR Journal of Agriculture and Veterinary Science; 2015; 8(11): 48-56. 